\title{
Blended Learning-Effectiveness and Application in Teaching and Learning Foreign Languages
}

\author{
Joel Laffita Rivera ${ }^{\circ}$ \\ Faculty of Applied Communication (FAC), Multimedia University, Cyberjaya, Malaysia \\ Email: Joel.laffita@mmu.edu.my
}

How to cite this paper: Rivera, J. L. (2019). Blended Learning-Effectiveness and Application in Teaching and Learning Foreign Languages. Open Journal of Modern Linguistics, 9, 129-144. https://doi.org/10.4236/ojml.2019.92013

Received: March 20, 2019

Accepted: April 27, 2019

Published: April 30, 2019

Copyright (อ 2019 by author(s) and Scientific Research Publishing Inc. This work is licensed under the Creative Commons Attribution International License (CC BY 4.0).

http://creativecommons.org/licenses/by/4.0/

\section{(c) (i) Open Access}

\begin{abstract}
The present research paper is designed to investigate the importance of the application of Blended Learning (BL) in education as a method for teaching and learning Foreign Languages Subjects (FLs) at university level. The study has used the mixed-method approach for the collection of data and its analysis. The study discloses: The research-design; Foreign Language-framework; Teaching and learning-roleplay-reflection and Methodology-schemes. Although the employment of BL is very important in teaching and learning practices; the paper-results concluded that there is a need to provide methodologies and computer training sessions to the FL teachers for effective employment of BL in foreign languages classes. Consequently to this the study aimed to deliver an applicable script through which Spanish language teachers and foreign language teachers obtain pedagogical-and computer knowledge-inputs to setup foreign languages classes through Blended Learning.
\end{abstract}

\section{Keywords}

Blended Learning, Spanish as Second Foreign Language, Teaching, Learning, Online Tools, Applied-Didactic, Classroom Management

\section{Introduction}

Teaching and learning a foreign language is not an easy task to accomplish as it takes into account the challenges of all kinds that both teachers and students have to face from the beginning of the teaching and learning process of this honorable discipline. Many are the encounters related to education, culture, religion and language background to be cited. However, when it comes to teach and learn a foreign language subject it is possible to overcome most of these chal- 
lenges as a result of the application of the Blended Learning, for instance, the hundreds of YouTube videos put at our disposal in Internet. These onlinecommunication-tools cover much of the FL topics to be taught in a FL class and make possible to conduct the teaching and learning of this subject by using the BL Method. According to (Skrypnyk et al., 2015) ${ }^{1}$ BL is defined as a Tech-Instructive Approach and its main objective is to use the technological advances of the Digital Era to benefit the Education sector in general. The term Blended learning is used to describe the way that e-learning is combined with traditional classroom methods and creates a hybrid teaching methodology. in other words, the best from the Old and the New as one. The blended technology with traditional teaching methods offers more opportunities for teachers to use several different and effective teaching methods. Different learning styles can be accommodated allowing that way to answer one of the most difficult classroom-setting issue. Even though the application of BL represents a much greater change in basic technique than simply adding computers to classrooms; the self-learning, comprehension, and retention of information among the second language learners can be improved through the use of BL. As said by (Beetham \& Sharpe, 2013) the use of technologies offers the opportunity to manage the teaching and learning process of a foreign language smoothly. Today, information and communication technologies are probably the most used technologies for foreign language teaching. By taking into account this Introduction-View the following headings and sub-headings are addressed.

\section{Literature Review}

Blended learning plays a significant role to enhance foreign language skills. The implication of blended learning has been proved effective in improving foreign language skills, but there is lack of willingness of teachers to adopt this technology in their teaching style. Asiri et al. $(2012)^{3}$ has identified certain barriers, which are mostly faced by the administration of universities during or after the application of blended learning processes or e-learning system. The association between blended learning and the students' achievements in the classroom has been investigated by Al-Qahtani and Higgins $(2013)^{4}$. The findings have statistically significant difference between the implementation of blended learning processes and students' achievements. E-learning tends to represent broader domain of development and research activities into the application of technologies to education (Conole \& Oliver, 2006) ${ }^{5}$. It provides multimedia support to

${ }^{1}$ Skrypnyk, O., Joks, S., Kovanovic, V., Dawson, S., Gasevic, D., \& Siemens, G. (2015). The History and State of Blended Learning. Alberta: Athabasca University.

${ }^{2}$ Beetham, H., \& Sharpe, R. (2013). Rethinking Pedagogy for a Digital Age: Designing for 21st Century Learning. Abingdon-on-Thames: Routledge.

${ }^{3}$ Asiri, M. J. S., bt Mahmud, R., Bakar, K. A., \& bin Mohd Ayub, A. F. (2012). Factors Influencing the Use of Learning Management System in Saudi Arabian Higher Education: A Theoretical Framework. Higher Education Studies, 2, 125. https://doi.org/10.5539/hes.v2n2p125

${ }^{4}$ Al-Qahtani, A. A., \& Higgins, S. E. (2013). Effects of Traditional, Blended and e-Learning on Students' Achievement in Higher Education. Journal of Computer Assisted Learning, 29, 220-234. https://doi.org/10.1111/j.1365-2729.2012.00490.x 
the educational process using modern information and communication technologies usually implemented through computer networks. According to Westberry $(2009)^{6}$, BL enhances higher cognitive skills, promotes reflection, and gives equal opportunities to learners. It also provides cost-efficient, collaborative learning and encourages learners to communicate with instructors and peers and develops learners' skills (Lai \& Kritsonis, 2006) ${ }^{7}$. The environment provided in BL environment is more suitable to academic institutions and perceived as broader and more inclusive than distance learning and computer-assisted language learning. Lopez-Perez et al. $(2011)^{8}$ argued that BL was capable of improving the learning outcomes. The results stated that the attrition rates of students were decreased and their understanding was increased as a result of using online learning materials. Some of the advantages associated with BL included easy access to knowledge, improve pedagogy, cost-effectiveness, ease of revision of learning content, and personal presence. BL improved vocabulary of ELE learners cooperative learning increased the student involvement in learning. The learners show a mayor motivation and interest when they meet face-to-face and during class discussions with their peers in BL setting. BL tends to open new potentials for self-learning, lifelong learning, and raising students' achievement. A study conducted by Banados (2006) ${ }^{9}$ confirmed that successful implementation of BL in learning language may result in remarkable improvement in speaking skills along with important improvements in all skills.

\section{The Study Design}

The study has applied mixed research methods that include quantitative and qualitative techniques. It has focused on collecting, analyzing, and mixing both quantitative and qualitative data in a single study or series of studies. However, the study has used mixed approach because both quantitative and qualitative research work together offer the best understanding that can answer the research question. It tends to offer all possibilities offered by the approach to answer the research problem that help in the development of confidence in the study results. The study has recruited foreign language teachers from Multimedia University (MMU) Cyberjaya and Melaka campuses and Aula Cervantes de Kuala Lumpur, Malaysia. Teachers from these universities were given a questionnaire to get filled. The questionnaire was comprised of two sections. The first section ${ }^{5}$ Conole, G., \& Oliver, M. (2006). Contemporary Perspectives in E-Learning Research: Themes, Methods and Impact on Practice. London: Routledge. https://doi.org/10.4324/9780203966266. ${ }^{6}$ Westberry, N. (2009). An Activity Theory Analysis of Social Epistemologies in Tertiary-Leve e-Learning Environments. Unpublished Doctoral Dissertation, Hamilton: University of Waikato.

${ }^{7}$ Lai, C., \& Kritsonis, W. (2006). The Advantages and Disadvantages of Computer Technology in Second Language Acquisition. National Journal for Publishing and Mentoring Doctoral Student Research, 3, 1-6.

${ }^{8}$ Lopez-Perez, M. V., Perez-Lopez, M. C., \& Rodriguez-Ariza, L. (2011). Blended Learning in Higher Education: Students' Perceptions and Their Relation to Outcomes. Computers and Education, 56, 818-826. https://doi.org/10.1016/j.compedu.2010.10.023

${ }^{9}$ Banados, E. (2006). A Blended Learning Pedagogical Model for Teaching and Learning EFL Successfully through an Online Interactive Multimedia Environment. CALICO Journal, 23, 533-550 https://doi.org/10.1558/cj.v23i3.533-550 
collected background information and the second section consisted of 10 statements. See Table 1 Demographic Details and Table 2 Likert Scale Questionary. The data was collected via google forms-questionnaire that helped in assessing the current foreign languages practices by using $\mathrm{BL}$ at these universities. As a BL method combines traditional and modern methods with the use of technology for teaching and learning FL; all the statements in the questionnaire were set to measure the attitude of FL teachers towards BL from the standpoints of its education-impact concerning to set up learning outcome of FL subjcets; the improvement

Table 1. Demographic details.

\begin{tabular}{ccccc}
\hline $\begin{array}{c}\text { Academic } \\
\text { Qualification }\end{array}$ & $\begin{array}{c}\text { Years of } \\
\text { Experience }\end{array}$ & $\begin{array}{c}\text { Computer } \\
\text { Qualification }\end{array}$ & $\begin{array}{c}\text { Computer } \\
\text { Literacy Skills }\end{array}$ & $\begin{array}{c}\text { Foreign } \\
\text { Language Thought }\end{array}$ \\
\hline Bachelor & $1-5$ years & Diploma & Poor & Spanish \\
Master & $5-10$ years & Basic & Moderate & French \\
Ph.D. & $10-15$ years & None & Good & German \\
& $15-20$ years & & Excellent & Chinese \\
& 20 years & & & Korean \\
& & & & Japanese \\
& & & Arabic \\
\hline
\end{tabular}

Table 2. Likert scale questionary.

The integrated face to face and online teaching methods tend to produce better learning outcomes.

BL enhances the pedagogical knowledge of the teachers by creating a flexible learning environment for the students.

The interaction between student and teacher is enhanced as a result of using BL.

The application of BL in teaching foreign languages is effective.

The activities related to $\mathrm{BL}$ are demanding and it is difficult to manage time while implementing these activities.

The teachers are not confident in using BL to teach foreign languages to the students.

The teachers fear to lose control of the students while using BL in teaching foreign languages.

BL help the students to carry out their learning responsibilities effectively and increase their course satisfaction.

Teachers need appropriate training on the designing of BL courses and activities to teach foreign languages to the students.

The usage of BL in teaching foreign language should be made compulsory by the Ministry of Education.

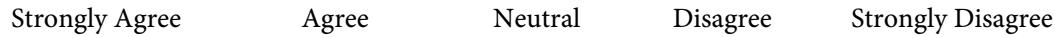


of the pedagogical knowledge of FL teachers when using it; the BL facilitation in communication between teachers and students; the BL effectiveness in the acquisition of the L2; the BL use to manage the timely; to evaluate the level of self-assured of FL teachers; the BL influence on the wellbeing of students; the need of BL training assistance and the stand of FL teachers in relation to $\mathrm{BL}$ Higher Education-measures. The responses of teachers were scored on the basis of 5 point Likert scale (strongly agree, agree, neutral, disagree and strongly disagree). After recording the responses, the completed online-questionnaire was collected and coded for statistical analysis.

\section{Foreign Language Reference-Spanish}

Español Como Lengua Extranjera (ELE) is the term used to refer to various systems used by different learning institutions that teach the Spanish language to speakers of other languages. There are many Institutions such as Official Language Schools, public and private schools, The Cervantes Institute and The Foundation for the Development of and Research into Spanish Culture (FIDESCU) for teaching and learning Spanish as Second Foreign Language. Nevertheless, when it comes to teach and learn Spanish as Second Foreign Language there are aspects of this particular language that needs to be known. For example, Español or Castellano as it is known is one of the easiest foreign languages to learn. The simple phonetics of Spanish language makes it easier to learn and speak irrespective of its grammar complexity (Rivera, 2019) ${ }^{10}$. In this aspect the use of BL in Spanish language classes benefits the acqisition of the L2. $\mathrm{BL}$ allows the beginner students to acquire and develop cognitive skills and language competences in a short period of time. The acquisition of vocabulary related to (greetings/introductions/responding/farewells/the Spanish alphabet-letters reading names) ext. it can be done by making a click. At present, there is not necessity for a Spanish language teacher to teach these aspects of the Spanish language and others by using the traditional method (teacher as center of the learning process). According to (Center for Research on Learning, 2011) ${ }^{11}$ the development of strategies for learning foreign language involves a set of operations and plans that assist in obtaining, storing, retrieving, and using important information. Furthermore, foreign language learners are motivated to understand and learn new information through their intentional behavior and thoughts. Reiterating the words "obtaining, storing, retrieving, and using important information" I would say that the use of BL will facilitates the ways to do as appropriate. And about "behavior" the way students behave in relation to the Second Language Acquisition (SLA), they cannot be segregated from the preferred way to study and learn. In other words, it is undeniable that the use of technologies has become a fundamental part of their lives and the preferred way

${ }^{10}$ Rivera, J. (2019). Applied Linguistic-Tú and Usted Spanish Personal Subject Pronouns. Open Journal of Modern Linguistics, 9, 12-24. https://doi.org/10.4236/ojml.2019.91002

${ }^{11}$ Center for Research on Learning (2011). Learning Strategies.

http://www.kucrl.org/sim/strategies.shtml 
to manage it in many areas, including school.

\section{BL-T \& L Roleplay Reflection}

According to (Motteram, 2013) ${ }^{12}$, the digital technologies help teachers working with learners, and assist learners to work independently to perform necessary "language" that makes their language development possible. The use of BL in teaching and learning foreign languages at university has to be in line with the learning style of the 21 st Century (Kramsch, 2014) ${ }^{13}$. In this regard working with university students for example, it is not the same thing as the school students because these students are one step away from becoming future professionals. In relation to this particular point the employing of $\mathrm{BL}$ as teaching and learning approach plays an essential role in cultivating the sense of self-responsibility among students, one of the qualities that the employers look at the most nowadays. As students are now center of teaching and learning process. The students play a major role of coordinator, builder as well as customer. As coordinators, students are responsible for their own language development. Consistent with this aspect, students have to deal with time management and completion of assigned tasks and the use of computer tools help to determine the level of discipline with which students assume their specific role. This is something very outstanding in providing good education to university students. In the Digital Era, teacher is no longer the center of teaching and learning process. Teacher functions as a facilitator, observant, and supervisor in particular, while using BL to conduct foreign language classes. As facilitator, the priority of a teacher is to equip the students with appropriate online didactic material, accompanied by clear instructions on what to. It will require knowledge of the subject to teach through the selection of appropriate online materials that match the language learning level of the students. The knowledge of the computer tool is used as channel to transfer the online language learning content. As a supervisor, the teacher monitors the language development of the students by providing useful strategies to facilitate communication and comprehension of the language taught. This will also require knowledge, the methodological capabilities of the lecturers, and the management and use of the class time and space. Moreover, as an observant, the main concern of a teacher is to pick up the mistakes of the students so that the corrections can be done as required. We are living in a Digital Age where updating our teaching and learning language methods so that they can be relevance to it; it must be a priority. We cannot ignore the learning style of the students these days and therefore the benefits of using the Blended Learning method. Even though this method has had its criticisms; it is quite effective from the perspective of developing the self-learning, which will produce self-confident; self-discipline and self-direct students. Consequently, if

${ }^{12}$ Motteram, G. (2013). Developing and Extending Our Understanding of Language Learning and Technology.

${ }^{13}$ Kramsch, C. (2014). Teaching Foreign Languages in an Era of Globalization: Introduction. The Modern Language Journal, 98, 296-311. https://doi.org/10.1111/j.1540-4781.2014.12057.x 
these are the qualities that we want our graduates university students to have!!! it seems to be that we have before our eyes one of the most appropriate method for teaching a foreign language subject at university level.

\section{Study Oriented-Approach}

According to what is approved by the Common European Framework of Reference for Languages or the CEFR (Consejo de Europa, 2001) ${ }^{14}$ there are six grades as well as six exams (A1, A2, B1, B2, C1 and C2). Based on this mandate from the CEFR the Syllabus-Learning Outcome (LO) for a foreign language course should be setup. Although every Education Institution has its own procedure to do as appropriate; the CEFR provides the International Standards Assignments Setting for FL subjects, including Spanish. Teaching Spanish as second foreign language either in Spain and Latin America or abroad, requires having knowledge of the language and methodological capabilities. Furthermore if the course includes the use of $\mathrm{BL}$, then, the knowledge of computer-tools is required as well. I do say this because learning outcomes are statements of what students know, and can do as a result of their respective courses of study. This statement clear indicates the role to play by the teachers who are in charge of delivering the course-teaching-learning materials. That academic and proved statement (LO) also defines present and future outputs of any kind of study course. For this reason this research article is providing insights into a various facets of teaching and learning Spanish as Second Foreign Language with emphasis on BL-Benefit/Apllication. This method can be adaptable to other foreign language subjects.

\section{Course Name: Spanish for Beginners A1}

Objective \& Learning Outcome: This course is designed for equipping students with the communication and linguistic skills, specifically related to speaking and writing. At the end of the course students will be able to:

- Apply basic verbal communication;

- Demonstrate comprehension of basic verbal communication;

- Construct simple phrases/sentences and memos;

- Demonstrate comprehension of basic reading texts.

Based on what it is stated in the learning outcome the following didactic unit (Table 3 Lessons $1 \& 2$ ) is made up. A didactic unit is a kind of lesson plan, teacher details and describes each lesson of the course. In order to guide class instructions the teacher will develop this didactic unit, regarding skills, competences, time managing (how many time devote do each activity) and the explanations given to the students. Writing it, the teacher has to take into account what students have to learn during the course, how classes will be planned, and the different needs that students can present.

${ }^{14}$ Consejo de Europa (2001). Marco Común Europeo de Referencia para las Lenguas: Aprendizaje, enseñanza, evaluación. https://www.examenglish.com/CEFR/cefr_es.php 
Table 3. Didactic unit-lessons $1 \& 2$.

\begin{tabular}{|c|c|}
\hline Title & Do we know each other? \\
\hline Author & Joel Laffita Rivera. \\
\hline Level & A1. \\
\hline Competence & Communicative; Socio-cultural; Linguistic; Personal authonnomic. \\
\hline Objective & $\begin{array}{l}\text { To equip learners with basic Spanish language } \\
\text { communication skills. }\end{array}$ \\
\hline Homework & $\begin{array}{l}\text { BL given task; Practical exercises for pronunciation and } \\
\text { interactions in the target language; writing dialogues } \\
\text { and vocabulary enhancement. }\end{array}$ \\
\hline Grammar and Structure & $\begin{array}{l}\text { Verbs to be and to be called (ser/estar/llamarse); } \\
\text { subject pronouns-first/second/third (usted) } \\
\text { person singular/Simple and interrogative sentences. }\end{array}$ \\
\hline Vocabulary & Greetings and farewells. \\
\hline Function & $\begin{array}{l}\text { Informal/Formal Greetings; self-introductions; asking/saying } \\
\text { the name; responding; saying goodbye. }\end{array}$ \\
\hline Cultural Content & $\begin{array}{l}\text { Mannerisms (shaking hands/the kiss)/Name and last name/Hispanic } \\
\text { concept of proper etiquette. }\end{array}$ \\
\hline Pragmatic Content & $\begin{array}{l}\text { Open and ending dialogues (greetings/farewels)/Meaning } \\
\text { and coherence (responding). }\end{array}$ \\
\hline Session & 3 sessions ( 3 hour each). \\
\hline Material & $\begin{array}{l}\text { PowerPoint; Smartphone or tablet with Internet } \\
\text { connection/Computer tool applications; Whiteboard; } \\
\text { whiteboard mark; projector; lecturer notes. }\end{array}$ \\
\hline Evaluation & Online-quiz and Recorded-spoken dialogues. \\
\hline
\end{tabular}

\section{Computer Tool Applications}

The application of BL in FL classes requires the use of computer tool applications. It will be at the desire of the teachers to pick among many of those technological-advancements the most convenient to transfer the knowledge wanted to students. There are many computer tool applications accessible in Internet. Nevertheless, this study is presenting the following three (EDpuzzel/Khoot/Quizlet) because of their significant impact on teaching and learning practices. EDpuzzel counts with a vast community of language teachers whose are currently using this computer tool, its slogan cites "Make any video your lesson-Choose a video, give it your magic tough and track your students' comprehension". This is a true fact which gives FL teachers the opportunity to transform the selected video into an authentic-BL-work according to the teacher' expertise. What about Kahoot? Well, this computer tool is a game-based learning platform, used as educational technology in schools and other educational institutions. Its learning games, "Kahoots", are multiple-choice quizzes. Kahoot can be used to review students' knowledge, for formative assessment or as a break from traditional classroom activities (Center for Instructional Technology, 2015) ${ }^{15}$. In addition to this, Kahoot also provides the way to get statistic results which can be used to do re-

${ }^{15}$ Center for Instructional Technology (2015). 
search in the field of second language acquisition. According to analytical data Khoot counts with a community of monthly users of 50 million up to 2017. And Quizlet, what about Quizlet? This computer tool is a mobile and web-based study application that allows students to study information via learning tools and games. Quizlet trains students via flashcards and various games and tests. Thus, Quizlet is very convenient for "language setup tests-content" in particular. This computer tool allows FL teacher to do that according to the teacher' expertise. Based on data provided Quizlet is currently used by two-thirds of high school students and half of university students in the United States. From my own professional experience in using these computer tool applications in teaching Spanish language; I would say that FL teachers can create wonderful things and make the students feel that way too. See the captured of Figure 1 EDpuzzel and Figure 2 Kahoot and Figure 3 Quizlet. Internet Links related to these computer tool applications will be provided as attached in the sub-heading-Internet Accredited Sources.

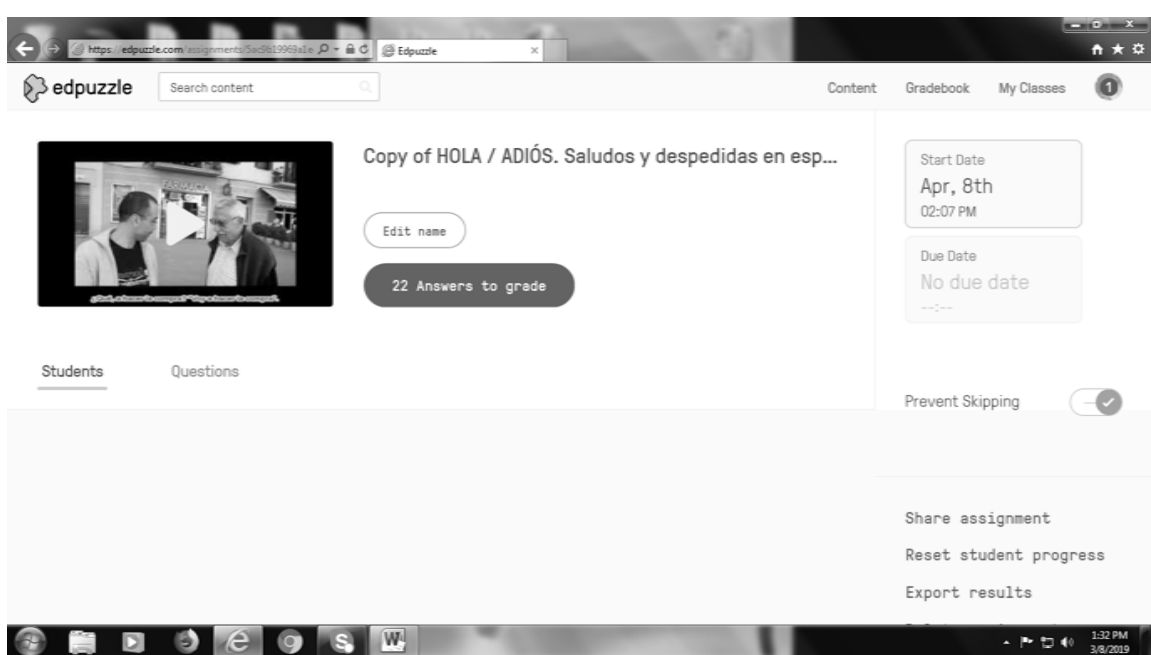

Figure 1. EDpuzzel.

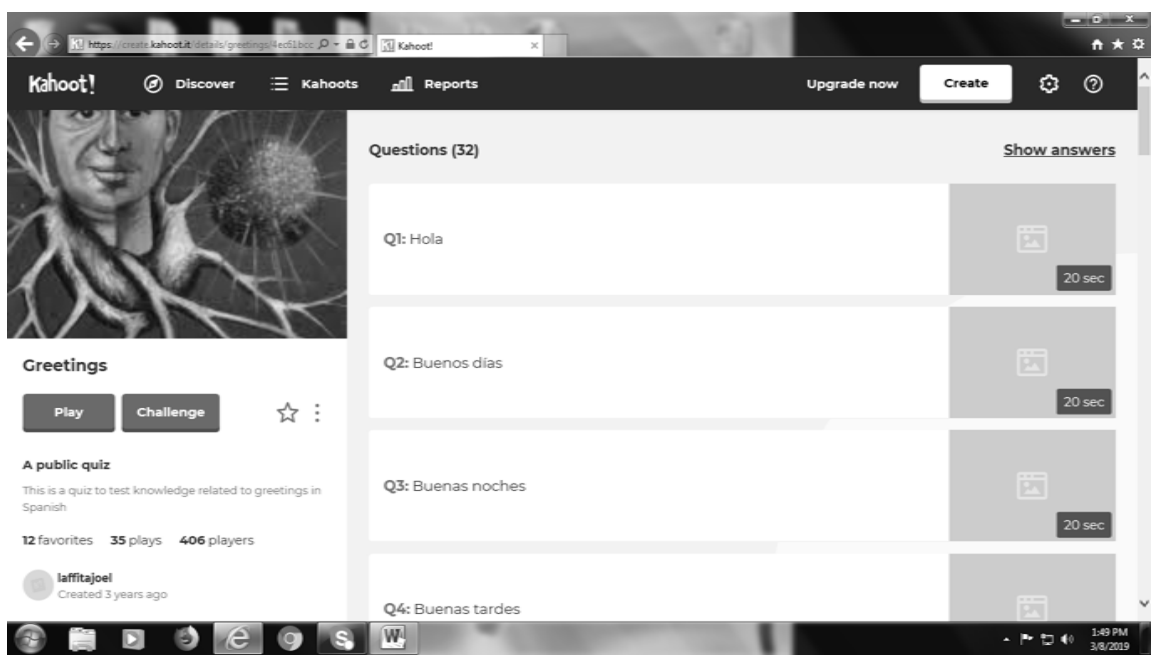

Figure 2. Kahoot. 


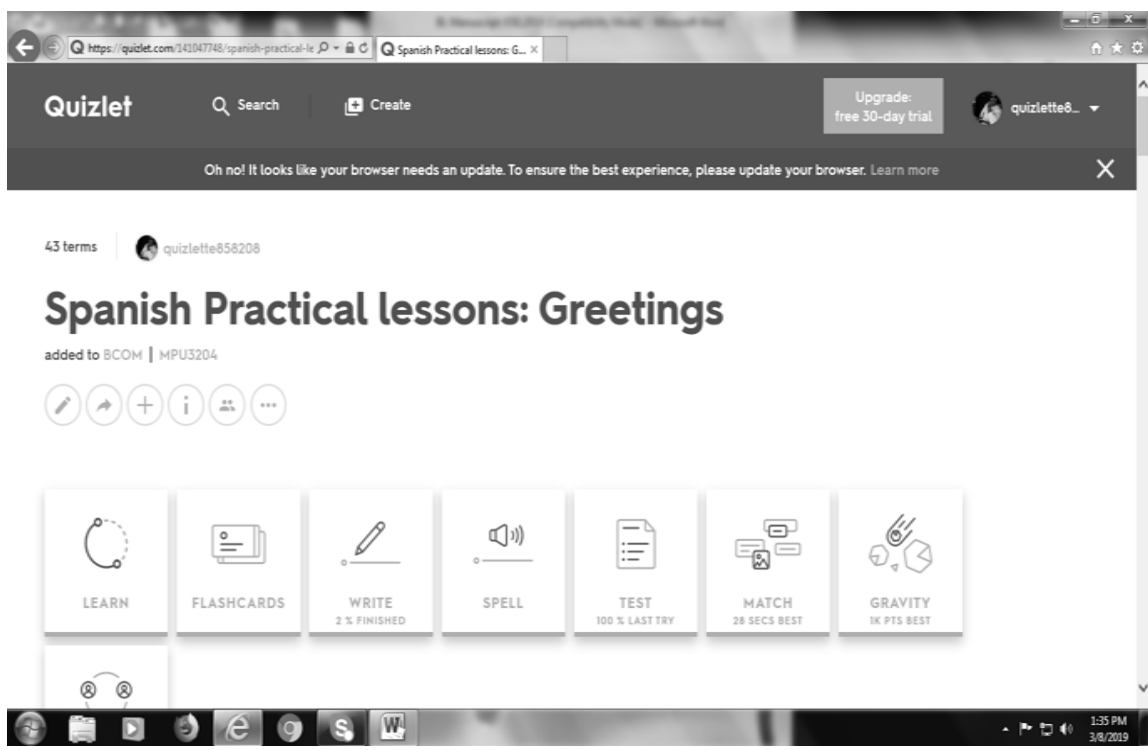

Figure 3. Quizlet.

\section{BL Class Management}

Activity 1-BL Given task. This activity is given to students in the class. It has to be accompanied by clear instructions on what students need to do in relation to the lesson-topic and the appropriate computer tool application-link and lecturer-note-link. The main focus of that lesson has to be on its communicatie objective. In a BL class the use of time and space is important. So, making clear to students the time they have to accomplish the goal. Arrange the classroom space so that they can communicate/discuss the lesson-subject-matter one with each other. Do not interrupt this learning process unless it is needed.

Activity 2-Class Discussion. This activity is to reinforce the knowledge acquired by students during the BL given task. The classroom space \& time is used to practice the pronunciation of the vocabulary learnt and to conduct individual and group interactions in Spanish language. During this activity make sure as a Spanish language teacher that students get a comprehension of the pronunciation and grammar used in the vocabulary learnt.

Activity 3-Vocabulary Enhancement. This activity is based on the lecturer' notes. Its purpose is to provide students "helpful Spanish Phrases" to enhance and empower the communicative-competence.

Activity 4-Testing Knowledge. This activity is a quiz-based lesson topic which requires the use of computer tools. In this case we use "Kahoot". It can be given to students as homework or for doing it in the class. It provides the way to get leraner' learning-retention-feebacks. This will help to identify students' weakness whether is individual or groups.

\section{BL Classroom Setting Disadvantages}

The following BL application disadvantages have been found in BL classroom-setting. From the first to the last they are related to the access that Inter- 
net-websites have on the others to do advertises, the Internet connection-mostly technical issues and speed, computer tools-cognitive-skills and the attitude of students towards BL.

- Distraction by non-relevant online content;

- Interruptions in the Internet connection;

- Problems with hardware-online tools;

- Insufficient knowledge about the use of computer-tools;

- Lack of discipline to carry out the BL given tasks in or out the class.

\section{Objective of the Research}

The study aim has been to provide an appropriate manuscript through which Spanish language teachers and foreign language teachers gain pedagogical and computer knowledge-inputs to setput foreign languages classes trough Blended Learning. The study has collected significant background information to materialize its contextual headings and sub-headings-finding in regard to the objective of the research article. Subsequently to these accounts the results and discussion and conclusion, as follow.

\section{Results and Discussion}

This study has conducted close observations based on the application of BL in Spanish language classes at first, and in other FL subjects conducted at Multimedia University (MMU), Malaysia. At present, in this Higher Learning Institution the use of BL in FL classes is an obligatory requirement. 30\% of FL class-delivering must be conducted through $\mathrm{BL}$, which provides the environment to do research referring to BL Method in teaching and learning practices. The statistics results about demographic details of the recruited teachers shows (57.1\%) were Masters' degree holders. $28.6 \%$ of the teachers hold bachelor's degree and $14.3 \%$ Ph.D. In relation to the years of experience among the teachers $14.3 \%$ of the teachers had experience of $1-5$ years. $28.6 \%$ of the teachers had experience of $5-10$ years and 10 - 15 years. $14.3 \%$ had $15-20$ and 20 years. Concerning the computer qualifications of the teachers, around $71.4 \%$ of the teachers had basic knowledge about computers; whereas, $28.6 \%$ had not knowledge about computers and $0 \%$ of the teachers had not diploma degree in computers. The computer literacy skills $42.9 \%$ of the teachers were good. $28.6 \%$ moderate and $28.6 \%$ had excellent skills, whereas, $0 \%$ of the teachers were not poor in computer literacy skills. About FL taught: Spanish 28.6\%, French; German; Chinese; Korean; Japanese $14.3 \%$ and Arabic $0 \%$. See Table 4 Demographic Details Statistics. The statistics result applied on the data to find the relationship between the statements provided in the questionnaire shows that (1st statement) $42.9 \%$ of the teachers agree while $28.6 \%$ strongly agree and $14.3 \%$ neutral and disagree and $0.0 \%$ strongly disagree. (2nd statement) $42.9 \%$ of the teachers agree and strongly agree. $14.3 \%$ neutral and $0.0 \%$ disagree and strongly disagree. (3rd statement) $42.9 \%$ agree, $42.9 \%$ neutral and $14.3 \%$ strongly agree and disagree and strongly disagree. (4th statement) 
Table 4. Demographic details statistics.

\begin{tabular}{|c|c|c|}
\hline Measure & Items & Percentage (\%) \\
\hline \multirow{4}{*}{ Academic Qualification } & Masters & $57.1 \%$ \\
\hline & Bachelors & $28.6 \%$ \\
\hline & $1-5$ years & $14.3 \%$ \\
\hline & $5-10$ years & $26.6 \%$ \\
\hline \multirow[t]{4}{*}{ Years of Experience } & $10-15$ years & $26.6 \%$ \\
\hline & $15-20$ years & $14.53 \%$ \\
\hline & $>20$ years & $14.3 \%$ \\
\hline & Diploma & $0.0 \%$ \\
\hline \multirow[t]{3}{*}{ Computer Qualification } & Basic & $71.4 \%$ \\
\hline & None & $28.6 \%$ \\
\hline & Poor & $0.0 \%$ \\
\hline \multirow{6}{*}{ Computer Literacy Skills } & Moderate & $28.6 \%$ \\
\hline & Good & $42.9 \%$ \\
\hline & Excellent & $28.6 \%$ \\
\hline & Spanish & $26.6 \%$ \\
\hline & French & $14.3 \%$ \\
\hline & German & $14.3 \%$ \\
\hline \multirow[t]{4}{*}{ FL Taught } & Chinese & $14.3 \%$ \\
\hline & Korean & $14.3 \%$ \\
\hline & Japanese & $14.3 \%$ \\
\hline & Arabic & $0.0 \%$ \\
\hline
\end{tabular}

$71.4 \%$ agree and $28.6 \%$ strongly agree and $0.0 \%$ neutral, disagree, strongly disagree. (5th statement) $57.1 \%$ disagree, $28.6 \%$ agree, $14.3 \%$ neutral and $0.0 \%$ strongly agree and strongly disagree. (6th statement) $71.4 \%$ disagree, $14.3 \%$ neutral, $14.3 \%$ agree and $0.0 \%$ strongly agree and strongly disagree. (7th statement) $42.9 \%$ disagree, $14.3 \%$ neutral, $28.6 \%$ agree, $14.3 \%$ strongly disagree and $0.0 \%$ strongly agree. (8th statement) $85.7 \%$ agree, $14.3 \%$ strongly agree and $0.0 \%$ neutral, strongly agree, strongly disagree. (9th statement) $85.7 \%$ agree, $14.3 \%$ strongly agree and $0.0 \%$ neutral, agree, strongly disagree (10th statement) $42.9 \%$ agree, $42.9 \%$ neutral, $14.3 \%$ disagree and $0.0 \%$ strongly agree, strongly disagree. See Table 5 Likert Scale Questionary Statistics.

As can seem, the majority of teachers agree and strongly agree with those statements that reflex the helpfulness and application of BL in teaching and learning FL. But what is really remarkable is the percentage of the 9th statement because it comes to confirm that teachers need appropriate training on the designing of BL courses and activities to teach foreign languages to the students. Apart from these statistics results; this study discussed other research studies 
Table 5. Likert scale questionary statistics.

\begin{tabular}{|c|c|c|c|c|c|}
\hline Accounts & Strongly Agree & Agree & Neutral & Disagree & Strongly Disagree \\
\hline $\begin{array}{l}\text { The integrated face to } \\
\text { face and online teaching } \\
\text { methods tend to produce } \\
\text { better learning outcomes. }\end{array}$ & $28.6 \%$ & $42.9 \%$ & $14.3 \%$ & $14.3 \%$ & $0.0 \%$ \\
\hline $\begin{array}{l}\text { BL enhances the pedagogical } \\
\text { knowledge of the teachers } \\
\text { by creating a flexible learning } \\
\text { environment for the students. }\end{array}$ & $42.9 \%$ & $42.9 \%$ & $14.3 \%$ & $0.0 \%$ & $0.0 \%$ \\
\hline $\begin{array}{l}\text { The interaction between } \\
\text { student and teacher is } \\
\text { enhanced as a result of using BL. }\end{array}$ & $14.3 \%$ & $42.9 \%$ & $42.9 \%$ & $0.0 \%$ & $0.0 \%$ \\
\hline $\begin{array}{l}\text { The application of } \mathrm{BL} \text { in } \\
\text { teaching foreign } \\
\text { languages is effective. }\end{array}$ & $28.6 \%$ & $71.4 \%$ & $0.0 \%$ & $0.0 \%$ & $0.0 \%$ \\
\hline $\begin{array}{l}\text { The activities related to } \\
\text { BL are demanding and it is } \\
\text { difficult to manage time while } \\
\text { implementing these activities. }\end{array}$ & $0.0 \%$ & $28.6 \%$ & $14.3 \%$ & $57.9 \%$ & $0.0 \%$ \\
\hline $\begin{array}{l}\text { The teachers are not confident } \\
\text { in using BL to teach foreign } \\
\text { languages to the students. }\end{array}$ & $0.0 \%$ & $14.3 \%$ & $14.3 \%$ & $71.4 \%$ & $0.0 \%$ \\
\hline $\begin{array}{l}\text { The teachers fear to lose } \\
\text { control of the students } \\
\text { while using BL in } \\
\text { teaching foreign languages. }\end{array}$ & $0.0 \%$ & $28.6 \%$ & $14.3 \%$ & $42.9 \%$ & $14.3 \%$ \\
\hline $\begin{array}{l}\text { BL help the students to } \\
\text { carry out their learning } \\
\text { responsibilities effectively } \\
\text { and increase their } \\
\text { course satisfaction. }\end{array}$ & $14.3 \%$ & $85.7 \%$ & $0.0 \%$ & $0.0 \%$ & $0.0 \%$ \\
\hline $\begin{array}{l}\text { Teachers need appropriate } \\
\text { training on the designing } \\
\text { of BL courses and } \\
\text { activities to teach foreign } \\
\text { languages to the students. }\end{array}$ & $14.3 \%$ & $85.7 \%$ & $0.0 \%$ & $0.0 \%$ & $0.0 \%$ \\
\hline $\begin{array}{l}\text { The usage of BL in teaching } \\
\text { foreign language should be } \\
\text { made compulsory by the } \\
\text { Ministry of Education. }\end{array}$ & $0.0 \%$ & $42.9 \%$ & $42.9 \%$ & $14.3 \%$ & $0.0 \%$ \\
\hline
\end{tabular}

view and other methodologies have been evaluated in order to present this upright transcript. Furthermore a wide panorama about BL helpfulness and applications has been provided to prove the accuracy of this study. This outlook is accompanied by BL-T \& L Roleplay Reflection and FL reference and orientedmethod to respond to the research-outcome. Currently, there is a significant impact of technology among the FL teachers to transfer knowledge and access students' learning to get positive learning results, and there is no better way to 
achieve it than using BL as method. Thus, this study intends to emphasize the significant of applying BL in teaching and learning foreign languages, mainly at university level.

\section{Conclusion}

On examining the data provided throughout the headings and sub-headings in this research article, one could conclude that the manuscript contains significant literature sources corresponding to the main objective of the research article. The data presented in the manuscript contextualize clearly the subject-matter in regards to the teaching and learning of foreign languages through BL. The finding of the study is value and supported by the professional view of its author and the view of other researcher-works. Although, FL teachers are well-aware about the benefits of BL in teaching and learning practices, the results of this research article have drawn the need to provide methodologies and computer training sessions to the FL teachers for effective employment of $\mathrm{BL}$ in foreign languages classes. This manuscript is adding new values to the use of computer-language-field, which is a contribution to the continued enhancement and development of the teaching and learning of foreign languages, especially in the Digital Age.

\section{Acknowledgements}

The author is very thankful to all the associated personnel in any reference that contributed in/for the purpose of this research.

\section{Funding}

The research is not funded through any source.

\section{Conflicts of Interest}

The research holds no conflict of interest.

\section{References}

Al-Qahtani, A. A., \& Higgins, S. E. (2013). Effects of Traditional, Blended and e-Learning on Students' Achievement in Higher Education. Journal of Computer Assisted Learning, 29, 220-234. https://doi.org/10.1111/j.1365-2729.2012.00490.x

Asiri, M. J. S., bt Mahmud, R., Bakar, K. A., \& bin Mohd Ayub, A. F. (2012). Factors Influencing the Use of Learning Management System in Saudi Arabian Higher Education: A Theoretical Framework. Higher Education Studies, 2, 125. https://doi.org/10.5539/hes.v2n2p125

Banados, E. (2006). A Blended Learning Pedagogical Model for Teaching and Learning EFL Successfully through an Online Interactive Multimedia Environment. CALICO Journal, 23, 533-550. https://doi.org/10.1558/cj.v23i3.533-550

Beetham, H., \& Sharpe, R. (2013). Rethinking Pedagogy for a Digital Age: Designing for 21st Century Learning. Abingdon-on-Thames: Routledge.

Center for Instructional Technology (2015).

Center for Research on Learning (2011). Learning Strategies. 
http://www.kucrl.org/sim/strategies.shtml

Conole, G., \& Oliver, M. (2006). Contemporary Perspectives in E-Learning Research: Themes, Methods and Impact on Practice. London: Routledge. https://doi.org/10.4324/9780203966266

Consejo de Europa (2001). Marco Común Europeo de Referencia para las Lenguas: Aprendizaje, enseñanza, evaluación. https://www.examenglish.com/CEFR/cefr_es.php

Kramsch, C. (2014). Teaching Foreign Languages in an Era of Globalization: Introduction. The Modern Language Journal, 98, 296-311. https://doi.org/10.1111/j.1540-4781.2014.12057.x

Lai, C., \& Kritsonis, W. (2006). The Advantages and Disadvantages of Computer Technology in Second Language Acquisition. National Journal for Publishing and Mentoring Doctoral Student Research, 3, 1-6.

Lopez-Perez, M. V., Perez-Lopez, M. C., \& Rodriguez-Ariza, L. (2011). Blended Learning in Higher Education: Students' Perceptions and Their Relation to Outcomes. Computers and Education, 56, 818-826. https://doi.org/10.1016/j.compedu.2010.10.023

Motteram, G. (2013). Developing and Extending Our Understanding of Language Learning and Technology.

Rivera, J. (2019) Applied Linguistic-Tú and Usted Spanish Personal Subject Pronouns. Open Journal of Modern Linguistics, 9, 12-24. https://doi.org/10.4236/ojml.2019.91002

Skrypnyk, O., Joks, S., Kovanovic, V., Dawson, S., Gasevic, D., \& Siemens, G. (2015). The History and State of Blended Learning. Alberta: Athabasca University.

Westberry, N. (2009). An Activity Theory Analysis of Social Epistemologies in Tertiary-Level e-Learning Environments. Unpublished Doctoral Dissertation, Hamilton: University of Waikato.

\section{Additional References}

Allen, K. H. (2013). The How of Blended Instruction: Current Practices of North Carolina Teachers in One-to-One Schools. Cullowhee, NC: Western Carolina University.

Al-Rabadi, R. Y., \& Bataineh, R. F. (2015). Learning Strategies in Literature-Based Instruction: A Qualitative Study of Jordanian University Students. Journal of Teaching and Teacher Education (University of Bahrain), 3, 101-110.

https://doi.org/10.12785/jtte/030109

Bijeikiene, V., Rasinskiene, S., \& Zutkiene, L. (2011). Teachers' Attitudes towards the Use of Blended Learning in General English Classroom. Studies about Languages, 18, 122-127. https://doi.org/10.5755/j01.sal.0.18.420

Carmen Losada Aldrey, M. (2005). Las nuevas tecnologías y la enseñanza-aprendizaje del español lengua extranjera. In M. Cal, P. Núñez, \& I. M. Palacios (Eds.), Nuevas tecnologías en Lingüística, Traducción, y Ensenyanza de lenguas (pp. 181-202). (In Spanish)

Chamot, A., Meloni, C., Gonglewski, M., Bartoshesky, A., \& Keatley, C. (2007). Developing.

Comas-Quinn, A. (2011). Learning to Teach Online or Learning to Become an Online Teacher: An Exploration of Teachers' Experiences in a Blended Learning Course. Recall, 23, 218-232. https://doi.org/10.1017/S0958344011000152

Harb, I. (2013). The Effectiveness of Blended Learning Program on Developing and Retention of Palestinian Tenth Graders' Writing Skill. Magazine Skill, 2, 208-221.

https://doi.org/10.11648/j.edu.20130206.12

Hong, K. H., \& Samimy, K. K. (2010). The Influence of L2 Teachers' Use of Call Modes 
on Language Learners' Reactions to Blended Learning. Calico Journal, 27, 328-348. https://doi.org/10.11139/cj.27.2.328-348

Larsen, L. J. E. (2012). Teacher and Student Perspectives on a Blended Learning Intensive English Program Writing Course. Ames, IA: Iowa State University.

National Capital Language Resource Center. Autonomy in Language Learners: Learning Strategies Instructions in Higher Education.

Perera, I. (2010). What Will Users Expect from Virtual Learning Methods? A Conceptual Model to Analyze Future Leaning Method Enhancements. US-China Education Review, 7, 76-82.

\section{Internet Accredited Sources}

http://englishagenda.britishcouncil.org/sites/default/files/attachments/british_council_in novations_in_learning_technologies_for_elt.pdf

https://blended.online.ucf.edu/about/what-is-blended-learning

https://create.kahoot.it/register

https://edpuzzle.com

https://elearningindustry.com/history-of-blended-learning

https://en.wikipedia.org/wiki/Blended_learning

https://quizlet.com

https://www.britishcouncil.org/voices-magazine/the-benefits-new-technology-language-1 earning

https://www.mindflash.com/elearning/what-is-blended-learning

https://www.teachthought.com/learning/the-definition-of-blended-learning 